\title{
Exploration History and Geology of the Saptarshi Lamproites, Madhya Pradesh, India
}

\author{
K. Masun ${ }^{1}$, C. Krishna ${ }^{2}$, L. Pande ${ }^{3}$, D. Pekeski ${ }^{4}$ P. Sengupta ${ }^{2}$, S. K. Sharma ${ }^{2}$, A. Singh ${ }^{2}$, A.V. \\ Sthapak $^{2}$, A. Vaidya ${ }^{2}$ \\ ${ }^{1}$ Vaaldiam Resources Ltd., Canada $;{ }^{2}$ Rio Tinto Exploration India Ltd, India, ${ }^{3}$ Max New York Life Insurance, \\ India $;{ }^{4}$ Kraven Geological Inc., Canada
}

\section{Introduction and Discovery}

Rio Tinto entered the diamond industry in 1979 with the discovery of Argyle in Western Australia. Subsequent discoveries include Diavik in Canada and Murowa in Zimbabwe. The most advanced diamond project in Rio Tinto Exploration's (RTE) current global portfolio is the Saptarshi Project, located in the Bundelkhand region of northern Madhya Pradesh, India, where Rio Tinto has discovered a cluster of diamondiferous intrusions (Figure 1). An order of magnitude (OoM) study of the Saptarshi deposits will be completed in 2008 .

RTE entered India in the mid-1990's and has been exploring for diamonds since 2000. The company has explored more than $40,000 \mathrm{~km}^{2}$ on the Dharwar, Bundelkhand and Bastar cratons, discovering $>40$ kimberlites and lamproites. RTE has focussed on rapidly evaluating and prioritizing areas by regional gravel sampling, infill sampling of anomalous catchments, extensive ground geophysics, soil geochemical sampling, prospecting and drilling.

RTE targeted the Bundelkhand region in 2003 and made its first lamproite discovery at Saptarshi in 2004 after regional gravel sampling identified two anomalous catchments with Diamond Inclusion Field (DIF) chromite as the most abundant indicator mineral recovered, and lherzolitic pyrope and diamond present in a few samples. Infill sampling of anomalous catchments followed and several thousand line kilometers of ground magnetics data were collected. High priority targets identified from ground mag anomalies were followed up by soil sampling and prospecting. This led to the discovery of outcropping source rock adjacent to a coincident magnetic high and $\mathrm{Nb}$ soil anomaly. The target, B28, (subsequently named Atri), was drilled where the $\mathrm{Nb}$ soil concentration and magnetic high signal were coincident. Petrographically confirmed pyroclastic lamproite was intersected beneath several meters of colluvium in the vertical discovery hole. Four additional drill holes completed the initial testing phase in 2005. At this time a second lamproite, B8, was drilled $700 \mathrm{~m}$ to the north (Figure 2). The drill hole intersected a complexly altered magmatic olivine lamproite dyke with a true thickness of $20 \mathrm{~m}$.
Microdiamond test results for the discoveries led RTE to scope an OoM study in 2006: work has since included large diameter core drilling, surface bulk sampling and delineation drilling of Atri, the largest occurrence at $\sim 18 \mathrm{Ha}$. Exploration drilling in the prospect area is continuing: this has extended the B8 intercept at least $400 \mathrm{~m}$ along strike, and shown an adjacent target (B48) to be lamproitic (Figure 2). Three additional lamproites have been drill-confirmed, a fourth has been identified in trenched subcrop, and three further targets (including dyke-like shoots radiating west from Atri) are interpreted as lamproite based on soil geochemistry, geophysics and float (Figure 2). The geometry and size of these occurrences is constrained largely by soil geochemistry and ground geophysics that suggests they are small $(<0.1 \mathrm{Ha}$ to 2.5 Ha).

\section{Geological Setting and Lamproite Geology}

The Peninsular Indian Shield is constituted of four Archean Cratonic nuclei and intervening Proterozoic mobile belts (Figure 1). The Bundelkhand Craton is bound to the south by low grade metamorphic rocks of the Proterozoic Satpura mobile belt. Intracratonic basin sediments of the Vindhyan Supergroup overlie the craton marginal Satpura rocks. The Vindhyan sequence comprises monotonous sandstone, shale and

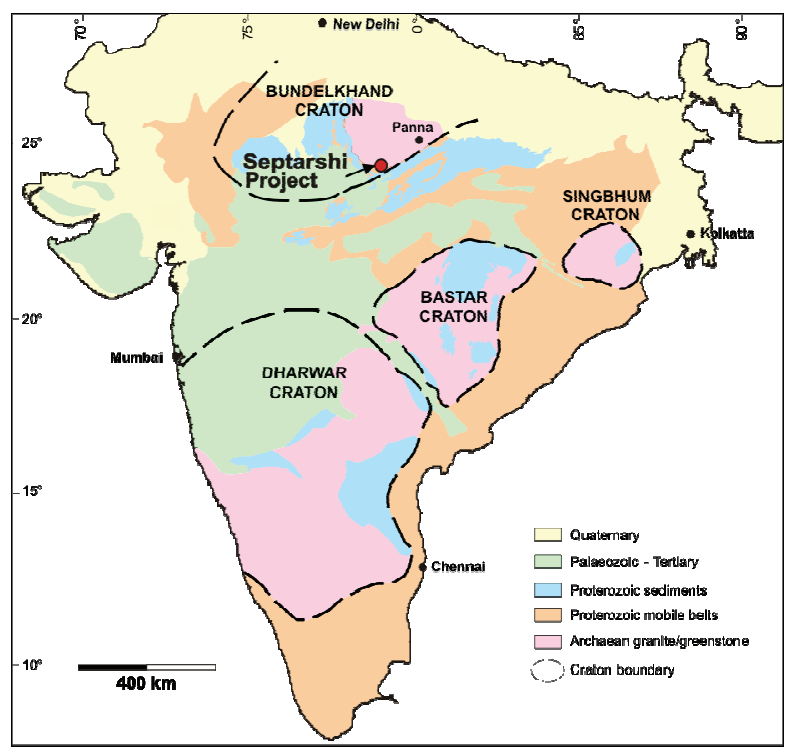

Figure 1. Generalized geology of and the location of the Saptarshi project. 


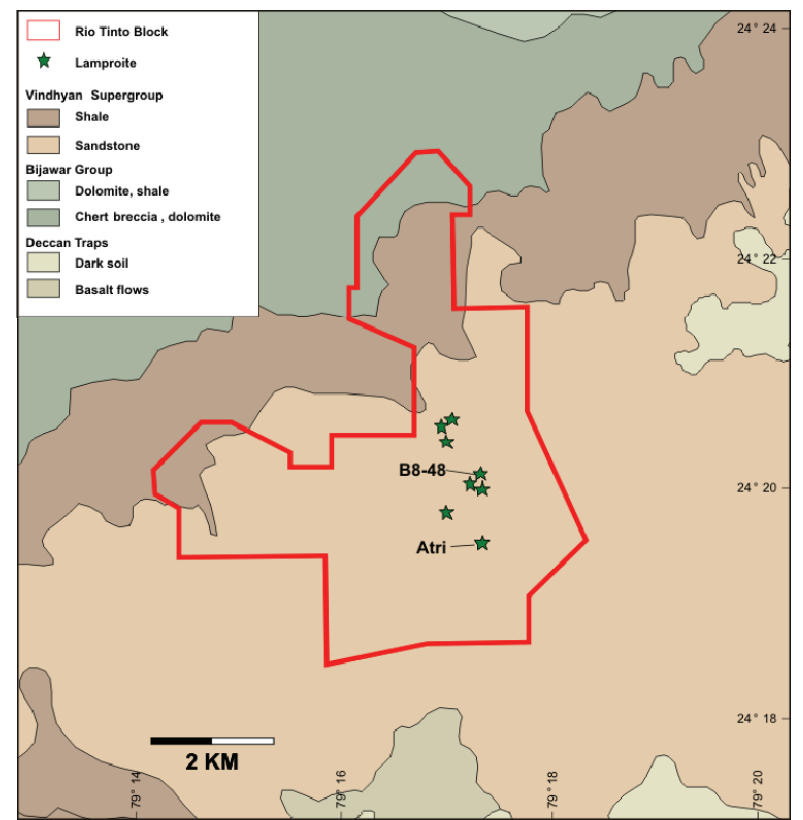

Figure 2. Simplified geology and the location of lamproites within Rio Tinto's Saptarshi property.

limestone units (thought to have been deposited between 1400-600 Ma.), with the Saptarshi lamproites emplaced into the Vindhyan Kaimur Group (Figure 2). A number of diamond-bearing horizons are found within these sediments. The Vindhyan Supergroup unconformably overlies Bijawar Group metasediments and metavolcanics, which comprise the Satpura mobile belt. A major unconformity separates the Satpura belt from the underlying Bundelkhand Granite Gneiss Complex (BGC). The total thickness of the sedimentary rocks above the crystalline basement at Saptarshi is unknown, but probably exceeds $500 \mathrm{~m}$. A very prominent NW-SE striking fracture system with a long history and periodic phases of reactivation likely provided local structural influence on lamproite emplacement.

Majhgawan, a potassic lamproite-like rock, was the first primary source of diamond recognized in India. It is located approximately $80 \mathrm{~km}$ ENE of Saptarshi, and intrudes the same stratigraphy as Atri. Majhgawan has been the only significant primary diamond deposit in India (Honota, $3 \mathrm{~km} \mathrm{NW}$ of Majhgagawan is of lesser significance).

The Atri lamproite is the largest confirmed body of the Saptarshi Lamproite cluster. It outcrops at surface in three locations (Figure 3). Current mapping and drilling suggests the pipe is $\sim 750 \times 250 \mathrm{~m}$ in size at surface and narrows with depth. Delineation drilling and surface outcrop observations indicate that the pipe wall angles differ significantly, from $83^{\circ}$ in exposed contacts and drill intercepts in the west to $\sim 67^{\circ}$ inferred by eastern drill intercepts. Modeling conducted from delineation drilling reveals that Atri comprises two lobes, north and south. One interpretation envisages two pipes that coalesce near surface. The bulk of the crater infill comprises pyroclastic lamproite that is variably (to intensely)

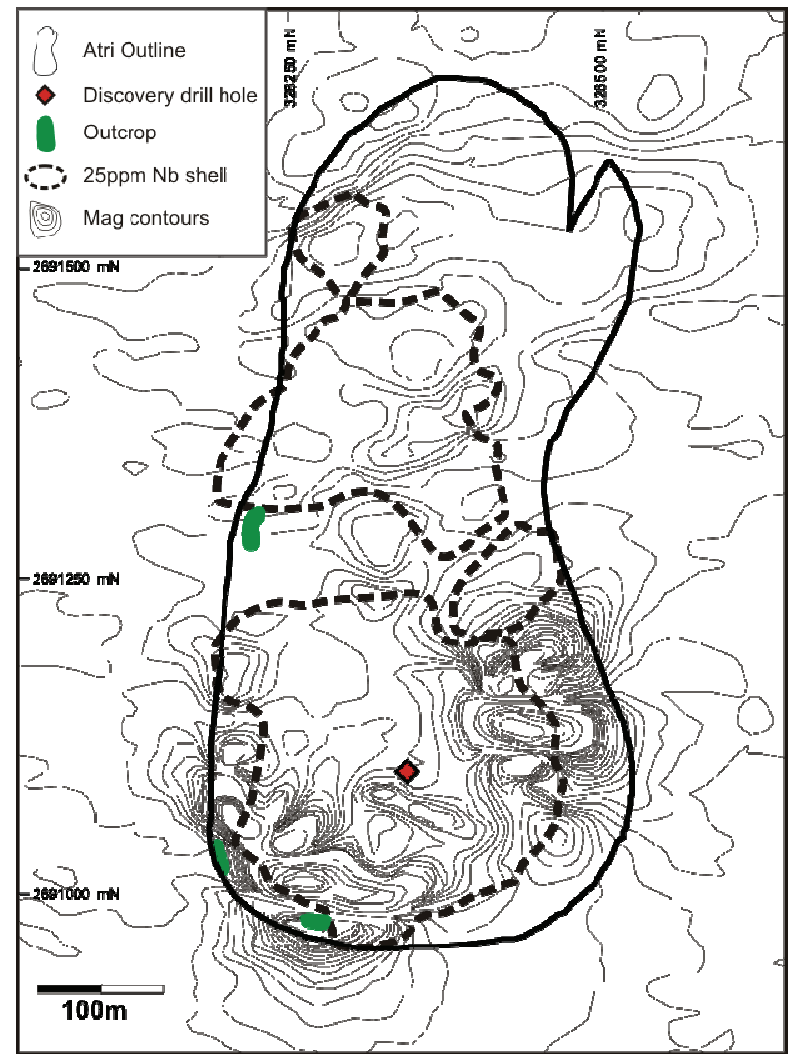

Figure 3. Exploration map of the Atri lamproite. UTM coordinates are WGS 84 (Datum), Zone 44 North.

altered. Contact breccias occur locally along pipe margins where significant fragments of the wall rock (sandstones, shales, dolomitic limestones) have been incorporated into the pipe; faulting and shearing occurs and some significant syn- and post-depositional faulting and slumping has occurred within the crater. Lamproite can be found as veins and stringers within the country rock, often extending up to $50 \mathrm{~m}$ from the pipe wall.

An $\mathrm{Rb}-\mathrm{Sr}$ emplacement age of $1064 \pm 15$ Ma was obtained for Atri and is broadly consistent with the $\approx 1100$ Ma Majhgawan and Hinota pipes, the kimberlites of the Dharwar Craton in South India and the Argyle lamproite in Western Australia.

\section{Discussion}

The geology and petrography of the Atri pipe shows similarities to the Majhgawan pipe (Masun, pers. obs.) and many parallels can be drawn between Atri and other lamproites. Pyroclasts do not exhibit convincing mineralogical or relict textural characteristics of kimberlite, although the mineral assemblage of olivine $>$ phlogopite $>>$ apatite does not preclude this classification. Other common primary mineral constituents include spinel and Ti-oxides. Olivine is never fresh and shows considerable resorption. The typical rounded macrocrysts of kimberlite are notably absent, whilst growth textures and complex euhedral to subhedral outlines are characteristic of the olivine in Atri and so resemble textures described in lamproite at other localities. Phlogopite phenocrysts and 
groundmass crystals petrographically suggest a significant tetraferriphlogopite component.

Per Mitchell (2006), it is suggested that Atri represents a local expression of potassic magmatism unique to the Bundelkhand Craton of India. Pending resolution of classification terminology for this rock class, Atri is classified as a lamproite (sensu lato).

Atri is comprised dominantly of pyroclastic phases with subordinate magmatic units. The pyroclastic rocks contain clasts of juvenile magmatic material (pyroclasts), olivine crystals and crystal fragments, cognate lamproite clasts, minor country rock xenoliths and an interclast matrix. The lamproite is highly altered; secondary minerals include carbonate, serpentine, chlorite, clays, talc and oxides.

Explosive emplacement is inferred from the dominant pyroclastic phases: their presence at depth in the pipe suggests that Atri was formed by pipe excavation and subsequent pyroclatic infill. The south lobe of Atri is filled with subaerial magmatic eruption products that show molding and welding and some large scale sorting, though there is no evidence of good sorting or fines retention suggestive of deposition in water. Thick intercepts of magmatic lamproite within the south lobe are thought to represent clastogenic lava. Lithology changes are typically a gradual transition from pyroclastic, unmolded lamproite, through molded and partially welded to coherent-textured lamproite.

The north lobe pyroclastics comprise pyroclasts that differ both in morphology and mineralogy from those of the south, being smaller, typically blocky and showing no textures typical of welding. The interclast matrix contains fines indicating a mode of deposition distinct from the south. No sharp contact between the lobes is recognised, and deposits with a mixed pyroclast population are common - though south-type clasts are invariably the subordinate constituent. The northern lobe was likely emplaced subsequent to the southern lobe, but prior to its lithification, possibly through column collapse. The mixing of pyroclasts from different eruptions that result in gradational boundaries has been reported by Webb et al. (2004) at the Victor pipe in Ontario Canada.

In general, the pyroclastic rocks of Atri are xenolithpoor. Some volcaniclastic lamproite is associated with a significant syn-or post emplacement fault structure that bisects the northeastern part of the pipe, but there is little other evidence of reworking.

\section{References}

Mitchell, R.H., 2006. Potassic Magmas Derived from Metasomatized Lithospheric Mantle: Nomenclature and Relevance to Exploration for Diamond-Bearing Rocks. Journal Geological Society of India 67 (3), 317-327.
Webb, K.J., Scott Smith, B.H., Paul, J.L., Hetman, C.M., 2004. Geology of the Victor Kimberlite, Attawapiskat, Northern Ontario, Canada: crosscutting and nested craters. Lithos 76(1-4), 2950 . 